\title{
Apoptosis-inducing Activity of Hot Water Extracts from the Sea Cucumber in Human Colon Tumor Cells
}

\author{
Mariko OGushi ${ }^{1,2 *}$, Yumiko Yoshie-STARK ${ }^{1}$ and Takeshi Suzuki ${ }^{1}$ \\ ${ }^{1}$ Department of Food Science and Technology, Faculty of Marine Science, Tokyo University of Marine Science and Technology, \\ Tokyo 108-8477, Japan \\ ${ }^{2}$ Department of Food Science, Sagami Women's University, Kanagawa 228-8533, Japan
}

Received December 6, 2005; Accepted August 18, 2006

\begin{abstract}
To study the anti-tumor activity of sea cucumber extracts, human colon adenocarcinoma Caco-2 cells were exposed to hot water extract of sea cucumber. Morphological changes with apoptotic bodies were observed in the cells treated with the extract. We demonstrated the induction of apoptosis using phosphatidylserine translocation (APOPercentage Assay kit), terminal deoxynucleotide transferase-mediated dUTP-biotin nick-end labeling (TUNEL), and DNA fragmentation observed as DNA ladder. These results show that apoptosis was induced by a high molecular weight fraction in a dose dependent manner. These data suggest that water soluble and high molecular weight compounds from sea cucumber might exhibit anti-tumor activity by triggering apoptosis. The apoptosis-inducing activity may contribute to cancer chemopreventive effects of sea cucumber.
\end{abstract}

Keywords: sea cucumber, hot water extract, Caco-2 cells, apoptosis

\section{Introduction}

In a previous paper (Ogushi et al., 2005), we demonstrated that a high molecular fraction of hot water extracts from sea cucumber inhibited the growth of Caco-2 cells in a dose dependent manner. Recently, several bioactivities have been detected in purified fractions from aquatic invertebrates including this echinoderm. Sulfated saponin was partly purified from the sea cucumber (Tong et al., 2005), and antitumor effect was also reported (Zou et al., 2003, Tian et al., 2005). The branched-chain fatty acid, 12- methyltetradecanoic acid extracted from the sea cucumber, also modulated PC3 cell growth (Yang et al., 2000). Konishi et al. (2006) reported apoptosis inducing activity of sea squirt derived compounds on cancer cell lines.

From these reports, sea cucumber was presumed to contain several potentially beneficial compounds. However, none of these authors have investigated the physiological effects of whole sea cucumbers as food. In the present study, we investigated the possibility that apoptosis induction may be involved in the growth inhibition effect found in sea cucumber extract.

\section{Materials and Methods}

Materials Sea cucumbers, Stichopus japonicus, were caught in the Sea of Japan (Nanao Bay, Ishikawa Pref., Japan) in March 2003. The samples were stored at $-30^{\circ} \mathrm{C}$

\footnotetext{
* To whom correspondence should be addressed.
}

E-mail: ogushi_mariko@isc.sagami-wu.ac.jp until use.

Preparation of extracts Sea cucumber extracts, hot water extract (HWE) and high molecular weight fractions (HMF), were prepared as described previously (Ogushi et al., 2005).

Cell culture and inhibition of cell growth Human colon adenocarcinoma, Caco-2, cells obtained from the Institute of Physical and Chemical Research (RIKEN Cell Bank, Ibaraki, Japan) were used to detect apoptotic cells (Konishi et al., 2006, Hosokawa et al., 2004). Caco-2 cells were cultured and maintained as described previously (Ogushi et al., 2005). Inhibition of cell growth of HWE and HMF was assessed using the cell counting Kit WST-1 (Wako Pure Chemical Industries, Ltd. Osaka, Japan) following the reports of Ishiyama et al. (1996). Cells were seeded in 96 -well plates with $1 \times 10^{3}$ cells/well in their specific medium supplemented with 10\% fetal bovine serum (FBS) (Invitrogen Corp., Carlsbad, California, U.S.A.). After 24 h, cells were exposed to serial dilutions of $\operatorname{HWE}(0,130,260,520$, $1040 \mu \mathrm{g} / \mathrm{mL})$ or $\operatorname{HMF}(0,13,54,81,108 \mu \mathrm{g} / \mathrm{mL})$ in medium supplemented with $2 \% \mathrm{FBS}$, and the plates were incubated for $96 \mathrm{~h}$. The $\mathrm{IC}_{50}$ was defined as the concentration that inhibited cell growth by $50 \%$ compared to that of control cells. Cell viability was assessed by trypan blue exclusion assay. Cells were seeded in 24 well plates with $1 \times 10^{5}$ cells/well in their specific medium with $10 \% \mathrm{FBS}$. After $24 \mathrm{~h}$, cells were exposed to serial dilutions of HWE $(0,250,500,750,1000 \mu \mathrm{g} / \mathrm{mL})$ or $\operatorname{HMF}(25,50,75,100 \mu \mathrm{g} / \mathrm{mL})$ in medium with $2 \% \mathrm{FBS}$, and the plates were incubated for $20 \mathrm{~h}$ and $96 \mathrm{~h}$. Cell viability was then determined using 
the trypan blue (Wako, Osaka, Japan) and hemocytometer. Results are expressed as the average \pm standard deviation $(n=3)$.

Morphological assessment of apoptosis Changes in the morphology of cell nuclei were examined by phasecontrast microscopy after addition of HMF. Caco- 2 cells $\left(5 \times 10^{5}\right)$ were plated in dishes of medium supplement with $10 \% \mathrm{FBS}$, and were cultivated for $24 \mathrm{~h}$. Cells were treated as follows: A, negative control (NC, sterile purified water); $\mathrm{B}$, positive control (PC, human recombinant TNF- $\alpha$ (Chemicon International, Harrow, UK) $25 \mathrm{ng} / \mathrm{mL}+$ sodium butyrate $5 \mathrm{mmol} / \mathrm{L}$; Jones et al., 2004); or C, HMF (100 $\mu \mathrm{g} / \mathrm{mL})$ in medium with $2 \% \mathrm{FBS}$ for $48 \mathrm{~h}$ and stained with Giemsa solution (Wako, Osaka, Japan).

Cytological detection of apoptosis by phosphatidylserine translocation The apoptosis-inducing effect of HMF to Caco-2 cells was determined using an APOPercentage Assay Kit (Biocolor Ltd., Northern, Ireland). Apoptosis in Caco-2 cells was examined qualitatively and quantitatively using the kit. This dye labels live cells bright pink that are undergoing phosphatidylserine translocation to the outer plasma membrane, a characteristic of apoptosis, but not necrosis (Johnson et al., 2003). Cells were either treated with $\operatorname{HMF}(25,50,75$, and $100 \mu \mathrm{g} / \mathrm{mL})$ or negative control (distilled water) in medium with $2 \%$ FBS. Caco-2 cells were exposed to HMF at various concentrations for $6 \mathrm{~h}$, and stained with APOPercentage dye. To quantify the occurrence of apoptosis cells in each group, the amount of dye extracted from cells were deter- mined by optical density at $570 \mathrm{~nm}$. Data are presented as the ratio (apoptosis index) of optic density in the treated cells to that observed in the control (negative control= 1.00 ; mean \pm S.D., $n=4$ ).

Quantification of apoptotic cells by TUNEL The effect of HMF on apoptosis was examined using an Apoptosis Screening Kit (Wako Pure Chemical Industries, Ltd., Osaka, Japan; the modified terminal deoxynucleotidyl transferasemediated dUTP nick end labeling; Gavrieli et al., 1992). Caco- 2 cells $\left(1 \times 10^{4}\right.$ cells/well $)$ were plated in 96 wells in medium supplement with $10 \%$ FBS, and were cultivated for $24 \mathrm{~h}$. Experimental cells were treated with HMF (25, 50,75 and $100 \mu \mathrm{g} / \mathrm{mL}$ ), while negative controls were treated as described above in medium with $2 \%$ FBS. After the cells were incubated for $6 \mathrm{~h}$, the plates were centrifuged at $250 \times \mathrm{g}$ for $5 \mathrm{~min}$. Apoptosis was detected using the Apoptosis Screening Kit. The cells were permeabilized and reacted with terminal deoxynucleotidal transferase (TdT) solution. The reaction product representing DNA fragmentation was detected by peroxidase-conjugated antibody. The optic density of $450 \mathrm{~nm}(655 \mathrm{~nm})$ in four wells per each treatment was measured by a microplate spectrophotometer. Data are presented as the ratio (apoptosis index) of optic density in the treated cells to that in the control (negative control $=1.00$; mean \pm S.D., $n=4$ ). In separate experiments, the Caco- 2 cells were treated using the same conditions, and viable cell number was determined using the WST-1 Assay Kit (Wako, Osaka, Japan).

Statistics The results represent the mean \pm standard

Table 1. Effects of sea cucumber extracts on the growth of Caco-2 cells.

\begin{tabular}{|c|c|c|c|}
\hline \multicolumn{2}{|c|}{$\begin{array}{l}\text { Hot water extract (HWE) } \\
\text { concentration }\end{array}$} & \multicolumn{2}{|c|}{$\begin{array}{l}\text { High molecular weight fraction (HMF) } \\
\text { concentration }\end{array}$} \\
\hline$\mu \mathrm{g} / \mathrm{mL}$ & rate of cell proliferation $(\%)$ & $\mu \mathrm{g} / \mathrm{mL}$ & rate of cell proliferation (\%) \\
\hline control & $100^{*}$ & control & $100^{*}$ \\
\hline 130 & $80.9 \pm 5.16^{d}$ & 13 & $74.9 \pm 8.78^{c}$ \\
\hline 260 & $62.6 \pm 7.42^{c}$ & 54 & $41.1 \pm 10.6^{b}$ \\
\hline 520 & $16.7 \pm 6.14^{b}$ & 81 & $16.3 \pm 3.58^{\mathrm{a}}$ \\
\hline 1040 & $0.9 \pm 1.75^{\mathrm{a}}$ & 108 & $6.1 \pm 4.55^{\mathrm{a}}$ \\
\hline
\end{tabular}

$\bar{*} 100 \%$ growth $=$ cell growth in control at $96 \mathrm{~h}$. Values are means \pm S.D. $(n=4-6)$.

Values with superscript letters were significantly different from the each other group $(p<0.01)$.

Table 2. Effects of sea cucumber extracts on the viability of Caco-2 cells.

\begin{tabular}{|c|c|c|c|c|c|}
\hline \multicolumn{3}{|c|}{ Hot water extract (HWE) } & \multicolumn{3}{|c|}{ High molecular weight fraction (HMF) } \\
\hline \multirow{2}{*}{$\begin{array}{c}\text { concentration } \\
\mu \mathrm{g} / \mathrm{mL}\end{array}$} & \multicolumn{2}{|c|}{ viability (\%) } & \multirow{2}{*}{$\begin{array}{c}\text { concentration } \\
\mu \mathrm{g} / \mathrm{mL}\end{array}$} & \multicolumn{2}{|c|}{ viability (\%) } \\
\hline & $20 \mathrm{~h}$ & $96 \mathrm{~h}$ & & $20 \mathrm{~h}$ & $96 \mathrm{~h}$ \\
\hline control & $96.3 \pm 2.16$ & $92.0 \pm 2.86$ & control & $96.3 \pm 2.16$ & $92.0 \pm 2.86$ \\
\hline 250 & $91.4 \pm 3.37$ & $56.3 \pm 9.03$ & 25 & $91.6 \pm 2.79$ & $57.7 \pm 6.74$ \\
\hline 500 & $87.8 \pm 2.52$ & $50.8 \pm 3.25$ & 50 & $85.6 \pm 4.03$ & $52.5 \pm 6.24$ \\
\hline 750 & $78.8 \pm 5.64$ & $25.2 \pm 1.18$ & 75 & $82.2 \pm 3.03$ & $28.8 \pm 7.80$ \\
\hline 1000 & $64.9 \pm 5.54$ & $19.5 \pm 4.46$ & 100 & $66.6 \pm 6.92$ & $11.9 \pm 1.87$ \\
\hline
\end{tabular}

(means \pm S.D., $n=3$ ) 
deviation $(n=3-6)$. Significant differences between samples were evaluated using an ANOVA.

\section{Results}

Inhibition of cell growth by HMF Table 1 shows the growth of Caco-2 cells in various extract concentrations [hot water extract (HWE) $\mu \mathrm{g} / \mathrm{mL}$ : 130-1040; high molecular weight fraction (HMF): $13-108 \mu \mathrm{g} / \mathrm{mL}$ ] after $96 \mathrm{~h}$ incubation. Both extracts clearly inhibited the proliferation of Caco-2 cells, as reported previously (Ogushi et al., 2005). The inhibitory effects were dose dependent, and cell proliferation was almost completely blocked by the $\mathrm{HMF}$ at $108 \mu \mathrm{g} / \mathrm{mL}$. In the case of HWE, no growth was observed at $1040 \mu \mathrm{g} / \mathrm{mL}$ after $96 \mathrm{~h}$ incubation. Concentrations of $50 \%$ inhibition $\left(\mathrm{IC}_{50}\right)$ were $3832 \pm 45$ and $48 \pm 6$ $\mu \mathrm{g} / \mathrm{mL}$ for HWE and HMF, respectively. The growth inhibition exhibited by HMF was comparable to that observed in 8-fold concentration of HWE, indicating the presence of potent inhibitors in this fraction with molecular weight above $1.2-1.6 \times 10^{4}$. In assessments of cell viability, dose-related decreases were observed after $20 \mathrm{~h}$ and $96 \mathrm{~h}$ exposure of extracts (Table 2).

Cell morphology After 24 h exposure to HMF, Caco-2 cells were Giemsa-stained and the possible change in the morphology was assessed under the phase contrast microscopy. The cells treated with TNF- $\alpha$ and butyrate were used as positive control (B). No clear change was observed in the negative control cells (A), but many HMFtreated cells (C) as well as positive control (B) cells showed shrunk or segmented nuclei, which are characteristics of apoptotic cells (Fig. 1).

When DNA fragmentation was analyzed, treatment of cells with HMF for $72 \mathrm{~h}$ at concentrations of 100 and 200 $\mu \mathrm{g} / \mathrm{mL}$ resulted in DNA ladder formation in gel electrophoresis (data not shown). The ladder bands for 180 and $360 \mathrm{bp}$ were detected in HMF-treated cells as in positive control cells, but clear dose-dependency with respect to ladder formation was not found in these experiments.

Cytological detection of apoptosis by phosphatidylserine translocation Many cells treated with HMF and positive control showed bright pink staining, indicating the occurrence of apoptosis in these cells (data not shown). This index increased with dose, and the value was 1.0, 1.11, 1.47 and 1.73 in those cells exposed to HMF at concentrations of 25, 50, 75 and $100 \mu \mathrm{g} / \mathrm{mL}$, respectively (Fig. 2).

TUNEL assay of apoptosis In these experiments, the cells were treated with increasing concentrations of HMF for $6 \mathrm{~h}$. As described in the previous section, the apoptosis index was determined in each group relative to the reaction in the negative control. The index was 1.40, 1.68, 2.15, and 1.93 at HMF concentrations of 25, 50, 75, and 100 $\mu \mathrm{g} / \mathrm{mL}$, showing an apparent dose-related increase in apoptosis in these cells, although no significant difference was noted between 75 and $100 \mu \mathrm{g} / \mathrm{mL}$ (Fig. 3).

\section{Discussion}

Sea cucumber was reported to exhibit inhibitory effects on proliferation of caco-2 human colon adenocarcinoma (Ogushi et al., 2005). In this study, significant cell growth inhibition at concentrations of 130-1040 $\mu \mathrm{g} \mathrm{HWE} / \mathrm{mL}$ and 13-108 $\mu \mathrm{g} \mathrm{HMF} / \mathrm{mL}$ was shown. The associated $\mathrm{IC}_{50}$ values were $383 \mu \mathrm{g} \mathrm{HWE} / \mathrm{mL}$, and $48 \mu \mathrm{g} \mathrm{HMF} / \mathrm{mL}$, respectively (Table 1). From these results, HMF was estimated to have the primary fraction responsible for cell growth inhibition.

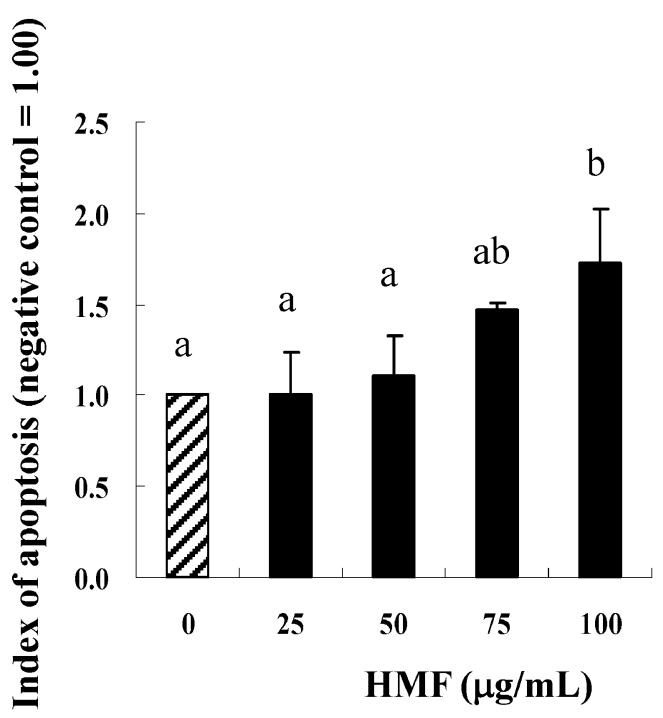

Fig. 2. Apoptosis identified by APOPercentage dye staining after $6 \mathrm{~h}$ to treatment.

Negative control cells (shadow column) and cells exposed to HMF at concentration of $25,50,75$, and $100 \mu \mathrm{g} / \mathrm{mL}$ (black column) are shown. Data are presented as the ratio of the index of apoptosis in the cells treated to the mean value of negative controls (the mean of negative control $=1.00$; mean \pm S.D., $n=5)$. The values with different letters were significantly different from each other $(p<0.05)$.
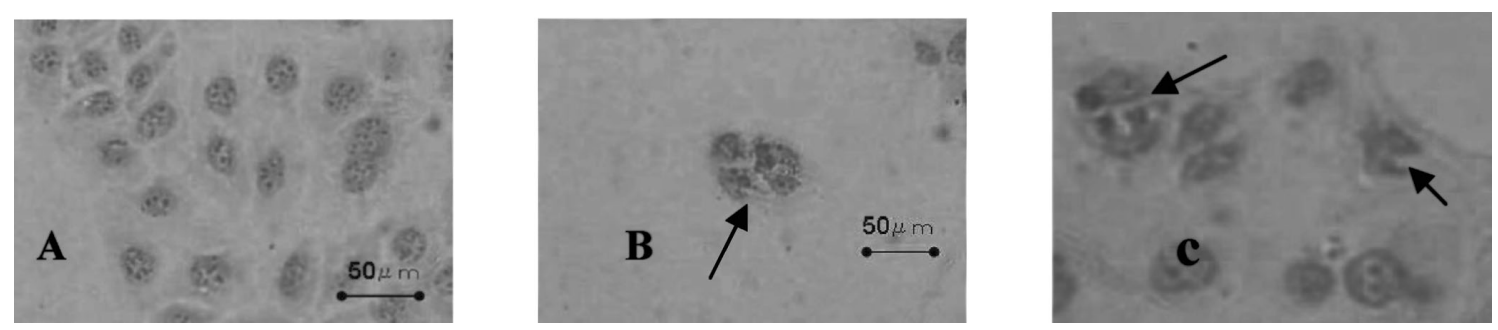

Fig. 1. Apoptotic bodies detected in HMF treated Caco-2 cells. A, negative control (untreated); B, positive control (TNF- $\alpha 25 \mathrm{ng} / \mathrm{mL}$ and butyrate $5 \mathrm{mmol} / \mathrm{L}$ ); $\mathrm{C}, 100 \mu \mathrm{g} / \mathrm{mL}$ of $\mathrm{HMF}$ for $48 \mathrm{~h}$. Apoptotic bodies are indicated by arrow. 


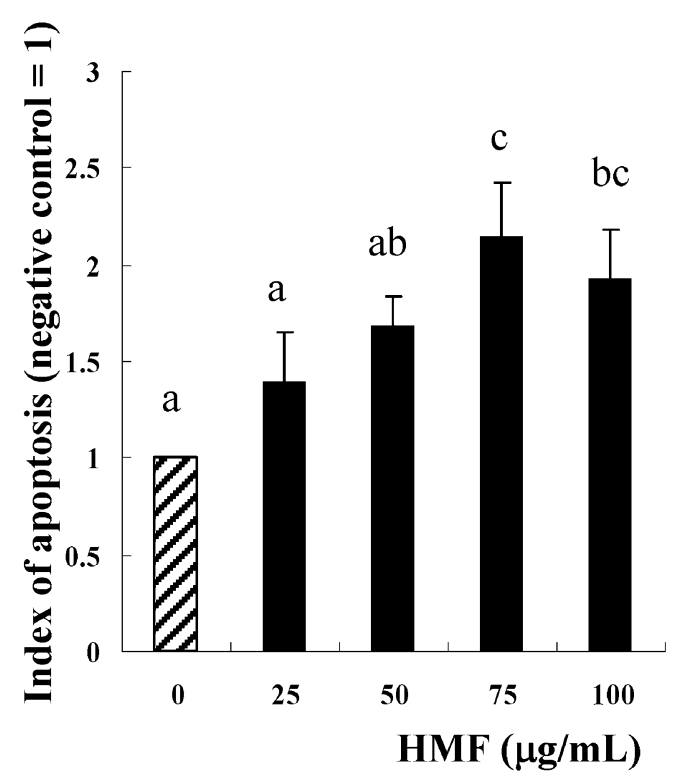

Fig. 3. Assessment of apoptosis by TUNEL analysis. Negative control cells (shadow column) and cells exposed to $\mathrm{HMF}$ at concentration of $25,50,75$, and $100 \mu \mathrm{g} / \mathrm{mL}$ (black column) are shown. Data are presented as the ratio of the index of apoptosis in the cells treated to the mean value of negative controls (the mean of negative control $=1.00$; mean \pm S.D., $n=4)$. The values with different letters were significantly different from each other $(p<0.05)$.

Konishi et al. (2006) reported the apoptosis-inducing effects of halocynthiaxanthin and fucoxanthinol isolated from sea squirt in caco-2 cells where the cell numbers measured using the WST-1 assay with $12.5 \mu \mathrm{mol} / \mathrm{L}$ fucoxanthinol were less than $20 \%$. This is similar to our results determined using WST- 1 with $520 \mu \mathrm{g} \mathrm{HWE} / \mathrm{mL}$ $(16.7 \%)$ or $81 \mu \mathrm{g} \mathrm{HMF} / \mathrm{mL}(16.3 \%)$ (Table 1$)$. In the present study, the viability of cells measured by trypan blue exclusion test after $20 \mathrm{~h}$ exposure was approximately $8 \%$ and $14 \%$ with $500 \mu \mathrm{g} \mathrm{HWE} / \mathrm{mL}$, and $75 \mu \mathrm{g} \mathrm{HMF} / \mathrm{mL}$, respectively (Table 2). These results suggest the presence of active compounds that were effective against cancer cells.

Apoptosis induction by HMF was evaluated by morphological and biochemical methods. Characteristic morphological and biochemical hallmarks of apoptosis, such as chromatin condensation, activation of cellular endonucleases, fragmentation of DNA and formation of apoptotic bodies, were detected in astrovirus-infected cells (Kerr, 1972). With regard to these characteristics, there was general agreement among results obtained with different techniques. It was known that apoptotic cells exhibited DNA fragmentation. In the preliminary experiments, DNA fragmentation was detected using bands of $180 \mathrm{bp}$ and $360 \mathrm{bp}$, suggesting that chromatin DNA was cut out to the size of nucleosome.

During the first stage of apoptosis, phosphatidylserine of membrane cells is known to be moving from the inner to the outer leaflet (Fodok et al., 1992). The APOPercent Dye kit can detect this movement of phosphatidylserine by staining. In this experiment, stained cells were col- lected and color strength was analyzed by spectrophotometry. Control cells were cultured without HMF and APOPercent dye, and the control value was calculated as 1.00 of the apoptosis index. After increasing the concentration of HMF to $75 \mu \mathrm{g} / \mathrm{mL}$, significant induction of apoptosis was detected with apoptosis index of 1.47 as compared to lower concentrations of HMF. An apoptosis index of 1.73 was exhibited at a concentration of $100 \mu \mathrm{g} / \mathrm{mL}$ of HMF, and this value was significantly larger than the values at concentrations of $50 \mu \mathrm{g} / \mathrm{mL}(p<0.05)$ (Fig. 2). This indicates that apoptosis was induced by HMF in a dose dependent manner.

When the TUNEL method was applied to this study, cells treated with HMF at concentrations of 25, 50, 75, and $100 \mu \mathrm{g} / \mathrm{mL}$ exhibited significantly more marked induction of apoptosis than control cells. The HMF-treated cells at concentrations of 25,50 , and $75 \mu \mathrm{g} / \mathrm{mL}$ also exhibited a dose-dependent increase in apoptosis. Taken together, the results of DNA fragmentation, APOPercent dye staining, and the TUNEL method, it was found that HMF from sea cucumbers was capable of inducing apoptosis.

Based on the findings of this study, the decrease in cell growth observed using sea cucumber extract prepared by standard cooking appears to be due to the induction of apoptosis. These results suggest the usefulness of sea cucumber as a chemopreventive foodstuff, or a potential source material for pharmaceutical products. Further research on sea cucumber extracts and their partially hydrolyzed samples are being undertaken in our laboratory to determine the changes in physiological activity caused by both cooking and digestion.

\section{References}

Fodok, V.A., Voelker, D.R., Campbell P.A., Chohen J., Bratton, D., L. and Henson, P. M. (1992). Exposure of phosphatidylserine on the surface of apoptotic lymphocytes triggers specific recognition and removal by macrophages. J. Immunol., 148, 2207-2216.

Gavrieli, Y., Sherman, Y. and Ben-Sasson, S.A. (1992). Identification of programmed cell death in situ via specific labeling of nuclear DNA fragmentation. J. Cell Biol., 119, 493-501.

Hosokawa, M., Wanezaki, S., Maeda, H., Kohno, H., Tanaka, T. and Miyashita, K. (2004). Fucoxanthin induces apoptosis and enhances the antiproliferative effect of PPAR $\gamma$ ligand, troglitazone, on colon cancer cells. Biochim. Biophys. Acta., 1675, 113119.

Ishiyama, M., Tominaga, H., Shiga, M., Sasamoto, K., Ohkura, Y. and Ueno, K. (1996). A combined assay of cell viability and in vitro cytotoxicity with a highly water-soluble tetrazolium salt, neutral red and crystal violet. Biol. Pharm. Bull., 19, 1518-1520.

Jones, S.A., Butler, R.N., Sanderson, I.R. and Wilson, J.W. (2004). The effect of specific caspase inhibitors on TNF- $\alpha$ and butyrateinduced apoptosis of intestinal epithelial cells. Exp. Cell Re., 292, 29-39.

Johnson, J.D., Ahmed, N.T., Luciani, D.S., Han, Z., Tran, H., Fujita, J., Misler, S., Edlund, H. and Polonsky, K.S. (2003). Increased islet apoptosis in Pdxl土mice. J. Clin. Invest., 111, 1147-1160.

Kerr, J.F., Wyllie, A.H. and Currie, A.R. (1972). Apoptosis: a basic biological phenomenon with wide-ranging implication in tissue kinetics. Br. J. Cancer, 26, 239-257.

Konishi, I., Hosokawa, M., Sashima, T., Kobayashi, H. and Miyashita, K. (2006). Halocynthiaxanthin and fucoxanthinol isolated from Halocynthia roretzi induce apoptosis in human leukemia, 
breast and colon cancer cells. Comp. Biochem. Physiol. C, 142, $53-59$.

Ogushi, M., Yoshie, Y. and Suzuki, T. (2005). Cytostatic activity of hot water extracts from the sea cucumber in Caco-2. Foood Sci. Tec. Res. 11, 202-206.

Tian, F., Zhang, X, Tong, Y., Yi, Y., Zhang, S., Li, L., Sun, P., Lin, L. and Ding, J. (2005). PE, a new sulfated saponin from sea cucumber, exhibits anti-angiogenic and anti-tumor activities in vitro and in vivo. Cancer Biol. Ther. 4, 874-882.

Tong, Y., Zhang, X., Tian F., Yi, Y., Xu, Q., Li, L., Tong. L., Lin, L. and Ding, J. (2005). Philinopside A, a novel marine-derived compound possessing dual anti-angiogenic and anti-tumor effects. Int $J$ Cancer, 114, 843-853.

Yang, P., Collin, P., Madden T., Chan D., Sweeney-Gotsch, B., McConkey, D. and Newman, R.A. (2003) Inhibition of proliferation of PC3 cells by the branched-chain fatty acid, 12-methyltetradecanoic acid, is associated with inhibition of 5-lipoxygenase. The Prostate, 55, 281-291.

Zou, ZR., Yi, YH., Wu, HM., Wu. JH., Liaw, CC. and Lee, KH. (2003). Intercedensides $\mathrm{A}-\mathrm{C}$, three new cytotoxic triterpene glycosides from the sea cucumber Mensamaria intercedens Lampert. J. Nat Prod., 66, 1055-1060. 